http://dx.doi.org/10.18778/1643-0700.20.02

Tomasz FIGLUS*

\title{
ZAGOSPODAROWANIE PRZESTRZENNE SZADKU W OKRESIE NOWOŻYTNYM W ŚWIETLE LUSTRACJI DÓBR KRÓLEWSKICH
}

Streszczenie. Artykuł prezentuje wyniki badań geograficzno-historycznych dotyczących zagospodarowania przestrzennego Szadku w okresie od XVI do XVIII w. Analizę przeprowadzono na podstawie materiałów źródłowych w postaci lustracji królewszczyzn z lat 1564, 1616, 1628, 1661 i 1789. Wiek XVI i początek XVII to okres dynamicznego rozwoju gospodarczego. Szadek obejmowało ok. 300 budynków mieszkalnych i kompleks dworski. W mieście rozwijał się handel i rzemiosło, o czym świadczą liczne kramy kupieckie i zakłady produkcyjne. W połowie XVII w. w wyniku zniszczeń wojennych rozpoczął się okres regresu. Nastąpił ogromny ubytek zabudów mieszkalnej, zanikowi uległo wiele istniejących wcześniej obiektów rzemieślniczych, podupadł handel, zaprzestano uprawy gruntów na przedmieściach. Pod koniec XVIII w. notuje się symptomy ożywienia gospodarczego. Obserwuje się wzrost liczby domów i poprawę stanu technicznego zabudowy, reaktywowano wiele obiektów usługowych i ponownie realizowano działalność produkcyjną, w tym rzemieślniczą i rolną.

Słowa kluczowe: Szadek, miasto, zagospodarowanie przestrzenne, lustracja, królewszczyzna, okres nowożytny

\section{WPROWADZENIE}

Celem artykułu jest przeprowadzenie analizy wybranych aspektów zagospodarowania przestrzennego miasta Szadek w okresie od XVI do XVIII w., które uchwytne są na podstawie jednej kategorii źródła historycznego, jakim

* Tomasz Figlus, dr, adiunkt, Uniwersytet Łódzki, Wydział Nauk Geograficznych, Katedra Geografii Politycznej, Historycznej i Studiów Regionalnych, 90-142 Łódź, ul. Kopcińskiego 31, e-mail: tomasz.figlus@geo.uni.lodz.pl. 
jest lustracja dóbr królewskich. Zagadnienie kształtowania oraz rozwoju społeczno-gospodarczego dawnych królewszczyzn stanowi niezwykle istotny element dziejów osadnictwa. Rysuje się wciąż niedostatek opracowań dotyczących badań regionalnych, bazujących na dostępnym materiale źródłowym. W odniesieniu do przyjętego obszaru analiz konieczne wydaje się uzupełnienie dotychczasowego stanu wiedzy związanej z kwestią zagospodarowania przestrzennego $\mathrm{w}$ epoce staropolskiej, która jest niewystarczająco rozpoznana w stosunku do możliwości źródłowych, zarówno w pracach monograficznych, jak i przyczynkarskich, $\mathrm{w}$ tym o charakterze popularnonaukowym ${ }^{1}$. Podstawę przeprowadzonych badań stanowiły dla autora materiały ujęte w postaci lustracji królewszczyzn z lat 1564-1565, 1616-1620, 1628-1632, 1659-1665 i 1789 r., dostępne zarówno w formie rękopisów zgromadzonych w Archiwum Głównym Akt Dawnych w Warszawie (w zespole Metryki Koronnej oraz Archiwum Skarbu Koronnego), jak i w formie dostępnych przedruków².

Początkowo Szadek i otaczające osady tworzące klucz majątkowy stanowiły formalnie część starostwa grodowego sieradzkiego. W 1588 r. doszło jednak do jego odłączenia od macierzystego starostwa i powstania starostwa niegrodowego z siedzibą w Szadku. W ten sposób w okresie kolejnych już lustracji królewszczyzn mamy do czynienia niezależną z dzierżawą szadkowską. Królewszczyzny stanowiły część majątku państwa, lecz tylko niektóre spośród nich, określane jako dobra stołowe, pozostawały w dyspozycji monarchy. Pozostałe dobra monarsze podlegały od końca XVI w. tylko pewnej kontroli ze strony reprezentantów Skarbu, a pozostawały w zarządzaniu posesorów (tenutariuszy). Lustracje dóbr królewskich przeprowadzane na podstawie konstytucji sejmowych z latach 1562-1563 były sporządzane w trzech egzemplarzach: jeden przechowywano w Metryce Koronnej, drugi w Archiwum Skarbu Koronnego, a trzeci pozostawał u tenutariusza lub zarządcy dóbr. Rewizje nadań, jak i lustracje dóbr królewskich

$1 \quad$ A.J. Parczewski, Monografia Szadku, Warszawa 1870; T. Marszał, Szadek. Monografia miasta, Szadek 1995; W. Puś, Dzieje Szadku do poczatku XVI w., „Na Sieradzkich Szlakach” 1995, R. 11, nr 3, s. 1; M. Wisińska-Kluba, Szadek w XVI-XVIII w., „Na Sieradzkich Szlakach” 1995, R. 11, nr 3, s. 5; J. Janczak, Ludność powiatu szadkowskiego w okresie Sejmu Czteroletniego, „Przeszłość Demograficzna Polski” 1975, t. 8, s. 3-55.

2 Lustracja województw wielkopolskich i kujawskich 1564-1565 (dalej: LWWK 1564), cz. 1, wyd. A. Tomczak, C. Ohryzko-Włodarska, J. Włodarczyk, Bydgoszcz 1961; cz. 2, wyd. A. Tomczak, Bydgoszcz 1963; Lustracja województw wielkopolskich i kujawskich. 1616-1620 (dalej: LWWK 1616-1620), cz. I, wyd. Z. Górski, R. Kabaciński, J. Pakulski, Wrocław-WarszawaKraków 1994; Lustracja województw wielkopolskich i kujawskich 1628-1632 (dalej: LWWK 1628-1632), cz. 2: Województwo sieradzkie, wyd. Z. Guldon, Wrocław-Warszawa-Kraków 1969; Lustracja województw wielkopolskich i kujawskich 1659-1665 (dalej: LWWK 1659-1665), cz. 2: Województwa sieradzkie, tęczyckie, brzesko-kujawskie, inowrocławskie i ziemia dobrzyńska, wyd. Z. Górski, J. Pakulski, A. Tomczak, Toruń 1996; Lustracja województw wielkopolskich i kujawskich 1789 (dalej: LWWK 1789), cz. 2: Województwo sieradzkie, t. 1: Powiaty sieradzki i szadkowski, wyd. R. Kabaciński, K. Mikulski, J. Pakulski, Toruń 2004. 
przeprowadzane były dla celów podatkowych przez organy delegowane przez sejm. Lustracje miały się odbywać co 5 lat, jednak przeprowadzono je w Koronie dla ogółu królewszczyzn tylko w 1 w latach: 1564-1565, 1569-1570, 1615-1620, 1628-1632 i 1659-1665, 1764-1765 i $1789^{3}$.

\section{LUSTRACJA SZADKU Z 1564 R.}

W inwentarzu zamków i dworów w starostwach, dzierżawach i folwarkach zlokalizowanych w dobrach monarszych na obszarze województw wielkopolskich z 1564 r. odnajdujemy opis zespołu dworskiego w Szadku. Jako formalnego dzierżawcę szadkowskiego wymienia się wówczas Stanisława z Tarnowa, wojewodę sandomierskiego, aczkolwiek faktycznym arendarzem był podstarosta Jan Raczyński, herbu Jastrzębiec ${ }^{4}$.

W lustracji ujęto dwa budynki mieszkalno-gospodarcze. W pierwszym z nich znajdowała się izba z okiennicami czterodzielnymi, wyposażona w długi stół. Za izbą była mała komora, a przed nią usytuowano sień z kominem i dwoma stołami dębowymi. Dalej znajdowała się kuchnia w złym stanie technicznym, z kominem glinianym i przyległą komorą oraz mała łazienka. Oprócz tego odnotowano obecność poprzedzonej sienią bielonej piekarni, z kominem murowanym, obejmującej niewielką komorę. Bezpośrednio przy dworze była stajnia na 26 koni. Lustratorzy wskazali ponadto na drugi budynek gospodarski. W jego obrębie znajdowały się w dwie izby bielone, $\mathrm{z}$ czego większa $\mathrm{z}$ nich wyposażona była w stół i komin murowany. Przylegała do niej komora. Z sieni można było dostać się również do drugiej komory oraz spiżarni. Zabudowania dworskie obejmowały budynki inwentarskie, w tym oborę w dobrym stanie oraz drewniane chlewy, a ponadto dwie drewniane stodoły5.

3 Szerzej: J. Senkowski, Lustracje, rewizje oraz inwentarze dóbr królewskich, [w:] J. Karwasińska (red.), Archiwum Główne Akt Dawnych w Warszawie. Przewodnik po zespołach, Warszawa 1973, s. 97-108; L. Żytkowicz, Lustracje dóbr królewskich XVI-XVIII wieku. Geneza i realizacja wydawnictwa, „Studia Źródłoznawcze” 1973, t. XVIII, s. 191-197; K. Górska, Przyczynek do krytyki rejestrów poborowych XVI wielu, „Studia Źródłoznawcze” 1957, t. 1, s. 184-189; Z. Guldon, Uwagi w sprawie przydatności badawczej rejestrów poborowych z XVI wieku, „Zapiski Historyczne" 1966, t. 31, nr 1, s. 73-80; K. Chłapowski, J. Dygdała, Prace edytorskie nad lustracjami dóbr królewskich XVI-XVIII w., po pótwieczu, „Studia Źródłoznawcze” 2005, t. 43, s. 161-171.

4 Herbarz polski Kaspra Niesieckiego, t. 8, Lipsk 1841, s. 4; AGAD, Metryka Koronna, ks. 85, k. 460; zob. A. Stoynowski, Użytkownicy królewszczyzn województw sieradzkiego i łęczyckiego oraz ziemi wieluńskiej (XVI-XVIII w.), „Rocznik Łódzki” 1975, t. 23, s. 315-329.

AGAD, Metryka Koronna, Lustracje, dz. XVIII, sygn. 8, k. 51; LWWK 1564, cz. 1, s. 63. 


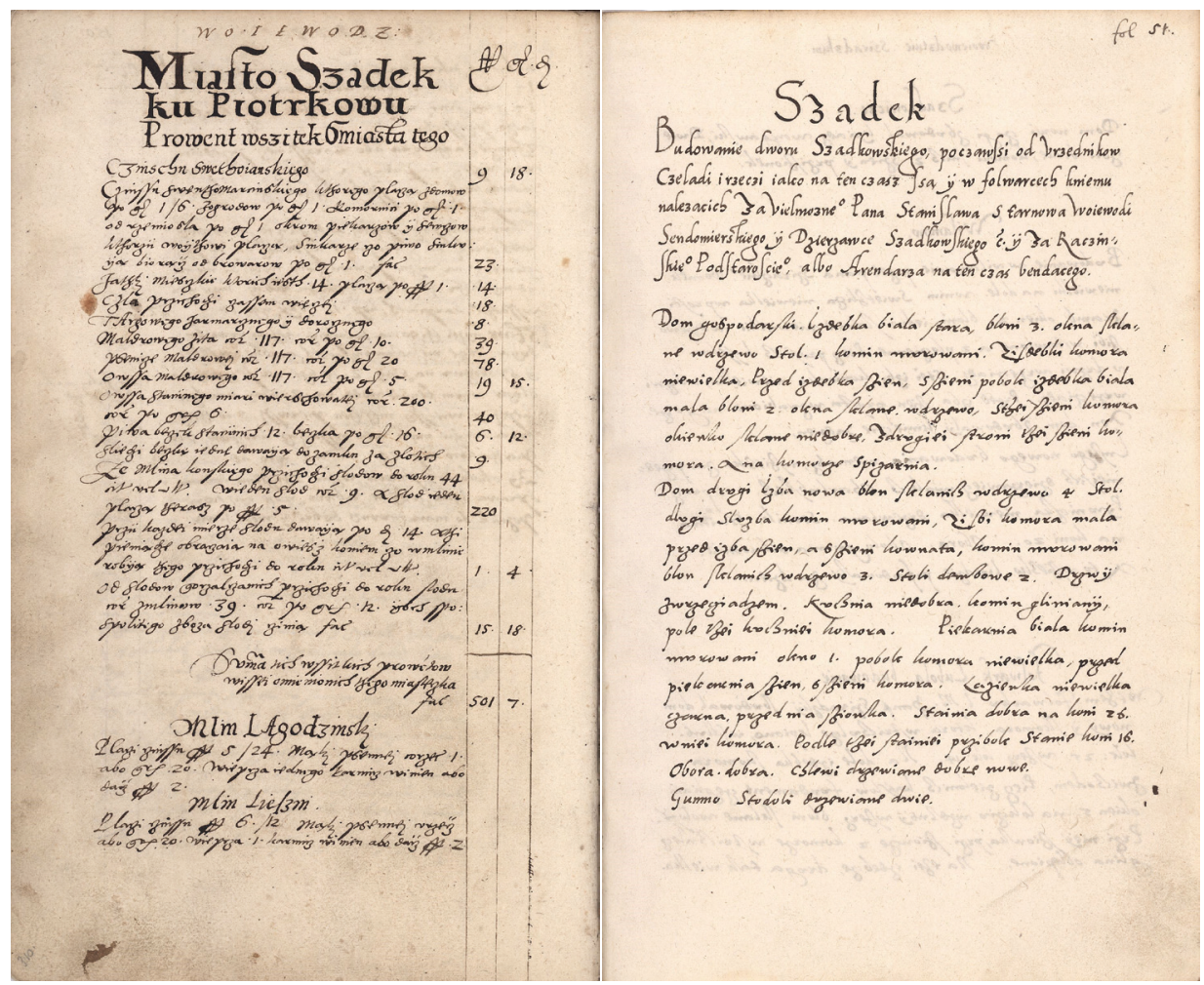

Ryc. 1. Fragment lustracji Szadku z 1564 r.

Źródło: AGAD, Metryka Koronna, Lustracje, dz. XVIII, sygn. 5, k. 150; sygn. 8, k. 51

Lustracja ukazuje szczegółowy wykaz źródeł pozyskiwania dochodów, co daje jednocześnie obraz specyfiki gospodarczej miasta. Sumaryczny dochód wynosił w tym czasie 501 florenów i 7 groszy ${ }^{6}$. Mieszkańcy zobligowani byli do płacenia czynszu (świętojańskiego i świętomarcińskiego), po 1 groszu i 6 denarów od domu, po 1 groszu z ogrodu, po 1 groszu od komorników, po 1 groszu od rzemieślników (w tym od szewców i piekarzy) oraz po 1 groszu od szynkarzy piwa. Łączny dochód z czynszów wynosił 32 floreny i 18 groszy, co daje ogólne wyobrażenie o stanie zaludnienia. W Szadku prowadzony był intensywnie handel, o czym świadczy dochód targowy i jarmarczny w wymiarze 8 florenów. Znajdowały się tu jatki miejskie w liczbie 14, które płaciły po 1 florenie. W Szadku prowadzona była produkcja słodu gorzałczanego w wymiarze 39 korców, po 12 groszy jeden. Prowadzony był również wyszynk piwa, w wymiarze 12 beczek stacyjnych, po 16 groszy jedna, co świadczy o istnieniu karczmy w mieście. W granicach miasta zlokalizowane były trzy młyny (Łagodziński, Leśny i Nowy). Młyny szad-

${ }^{6}$ W polskim systemie monetarnym w okresie nowożytnym 1 floren (złoty polski) $=30$ groszy. 
kowskie leżały na rzece Pichnnie, która przepływała przez miasto. Na podstawie danych o czynszach wnioskujemy również o istnieniu folusza w mieście. Łączny dochód z tytułu młynów i folusza wynosił w tym czasie 26 florenów i 28 groszy 7 .

\section{LUSTRACJA SZADKU Z 1616 R.}

Lustracja królewszczyzn przeprowadzona w 1616 r. przedstawia statystyki w zakresie zabudowy oraz struktury gospodarczej miasta. Na podstawie konsensu królewskiego w 1605 r. Mikołaj Zebrzydowski, herbu Radwan, przekazał prawa do dzierżawy szadkowskiej swojemu synowi Janowi ${ }^{8}$. Analiza dochodów z tytułu czynszu w dniu św. Marcina daje podstawę, by stwierdzić, że w Szadku znajdowało się w tym okresie 266 domów mieszkalnych (co dało dochód 11 florenów i 16 groszy). Lustratorzy wykazali ponadto istnienie 34 domów szlacheckich, których właściciele opierali się przed płaceniem należnych podatków. Znaczna liczba tego typu nieruchomości świadczy o randze miasta w strukturze osadniczej ze względu na status siedziby powiatu. Miasto zamieszkiwało łącznie 120 komorników. Była to grupa nieposesjonatów, rezydująca w domach mieszczańskich. Szczególną grupę społeczną stanowili „Podgórzanie”, w liczbie 18, którzy zamieszkiwali grunty królewskie pod miastem, gdzie doszukiwać się można genezy pierwotnej osady miejskiej ${ }^{9}$. Zobligowani oni byli nie tylko do czynszu i dziesięciny, ale również do pieszej pańszczyzny na rzecz dworu.

W świetle analizowanej lustracji można stwierdzić, że Szadek w I połowie XVII w. cechował się bogactwem warsztatów rzemieślniczych. W lustracji odnaleźć można wzmianki na temat 12 szewców (profesja wykazana również w poprzedniej lustracji). Oprócz tego odnajdujemy informacje o 18 kuśnierzach oraz grupie 24 rzemieślników reprezentujących ślusarstwo i kowalstwo. Do cechu tego przynależeli również garncarze, którzy czynili starania o osobny przywilej z uwagi na dyskryminację w podziale zysków. Statut tego cechu wydali burmistrz i rada miasta $\mathrm{w} 1618 \mathrm{r}$., co w tym samym roku potwierdził król ${ }^{10}$. Bardzo duże znaczenie w strukturze gospodarczej miasta zyskali natomiast sukiennicy, których zidentyfikowano w okresie lustracji aż 90, a ich czynsz dawał łącznie 3 floreny. W badanym okresie zmniejszyła się natomiast pozycja handlu. Po pożarze jatek miejskich, nie odbudowano ich. Z lustracji wynika ponadto, że opustoszał młyn koński, który do tej pory odpowiedzialny był za produkcję słodu piwnego, dla-

7 AGAD, Metryka Koronna, Lustracje, dz. XVIII, sygn. 5, k. 150-151; LWWK 1564, cz. 2 , s. $47-48$.

8 LWWK 1616-1625, cz. 1, s. 111.

9 Słownik geograficzny Królestwa Polskiego i innych krajów słowiańskich, t. XI, B. Chlebowski, W. Walewski (red.), Warszawa 1890, s. 760; M. Kulesza, Rozwój przestrzenny i współczesna struktura morfogenetyczna Szadku, „Biuletyn Szadkowski” 2003, t. 3, s. 56-58.

${ }^{10}$ LWWK 1616-1625, cz. 1, s. 112. 
tego mieszczanie tymczasowo w młynach królewskich, a nie czyich inszych, poko wody staje, mełać powinni, do czasu, gdy starosta nowego młyna końskiego nie postawi ${ }^{11}$. Część zysków ze słodów piwnych należała się mansjonarzom działającym od 1505 r. z fundacji J. Łaskiego przy kościele pw. Wniebowzięcia NMP i św. Jakuba ${ }^{12}$. Ogólny dochód z tytułu podatków w Szadku wynosił w analizowanym okresie 1251 florenów i 4 grosze.

\section{LUSTRACJA SZADKU Z 1628 R.}

Wykonana dekadę później kolejna lustracja przynosi bardzo dokładny opis zabudowań dworskich oraz szczegółową charakterystykę spraw gospodarczych. Posesorem dzierżawy szadkowskiej od $1622 \mathrm{r}$. był Mikołaj Wierzbowski, piszący się z Wielkiego Chrząstowa, kasztelan inowłodzki ${ }^{13}$. Analizę wyników lustracji $\mathrm{z}$ tego okresu rozpocznijmy od ujętej w materiale źródłowym wizytacji kompleksu dworskiego. Położony był on na odległość stajania ${ }^{14}$ od centrum miasta. Oprócz licznych budynków gospodarskich, znajdowały się tam dwory, określane jako stary i nowy, a także budowanie na kopcu (nasypie ziemnym) czyli domostwo z sienią, izbą ogrzewaną piecem, komorą, łazienką oraz kolejną izdebką ${ }^{15}$. Warto, ze względu na precyzję przeprowadzonej lustracji, przytoczyć in extenso fragmenty opisu zespołu dworskiego. Rozpoczyna się on słowami dotyczącymi nowego dworu i jego bezpośredniego otoczenia:

Do niego wjeżdzając, wrót dwoje dwoistych na biegunach, a kuny od wierzchu żelazne mające, gontami pobite, już przegniety. Do sieni drzwi drewniane na zawiasach, z wrzeciadzem, skoblem i klamka. W tej sieni przy izbie kuchenka tarcicami wkoto obwiedziona, ognisko drzewem okasztowane, komin prosty $w$ drzewo, glina oblepiony. Izba, do niej drzwi na zawiasach, z klamka i hantaba okien 5, szyby ze szkła prostego, w ołów wprawione, piec zielony kaflowy, komin prosty, niedobry, lawy proste po 2 stronach przy ścieniech, stót 1 szeroki, dębowy, drugi pomniejszy, zydlów 2, konewnik prosty z szafami prostemi, drzwiczki do nich na zawiasach. $Z$ tej izby komora (...) Z tej komory drzwi do komórki (...) Przy kuchni w sieni

11 AGAD, Archiwum Skarbu Koronnego, dz. XLVI, nr 104, k. 128-129v.

12 J. Łaski, Liber beneficiorum archidiecezji gnieźnieńskiej, wyd. J. Łukowski, t. I, Gniezno 1880, s. 440.

13 AGAD, Metryka Koronna, ks. 168, k. 96-97v.

14 Staropolska miara długości drogi, definiowana jako odległość przebyta przez konia pomiędzy dwoma odpoczynkami.

15 L. Kajzer, Dwór królewski - zapomniany zabytek Szadku, „Biuletyn Szadkowski” 2002, t. 2, s. 10-12. 
izdebka kuchenna (...) Przeciwko izbie komora (...) W tejże sieni drugie drzwi do piekarnie (...) Przy izbie na podwórzu komora do mleczna na dole, (...) Na tej komorze druga komora dla nabiatów. Nad tym wszytkim budowaniem dach przegniety, stary. W podwórzu lamus dla chowania rzeczy dachem gontowym pokryty, na poty pogniety (...) Pod tym lamusem piwniczka (...).

Dalej znajduje się opis starego budynku dworskiego i jego otoczenia:

W tymże podwórzu dwór stary, gdzie browar byt, stoma po większej części poszyty, gontami ostatek, i to zgnielemi pobity, przez który zaciekajac połap nad komora przegniet $i$ zawalet komore (...). To budowanie w ziemię wszystko wpadło, już dobrze pogniełe. Przy tym starym budowaniu 3 chlewiki, do których troje drzwiczek, stoma poszyte. Przy nich karmnik stoma także poszyty. Następnie możemy zapoznać się $z$ analiza wnętrz budynku: Tamże $w$ sieni kuchnia tarcicami obwiedziona, ognisko drzewem omasztowane, komin $w$ drzewo, glina polepiony. Izba (...), piec prostych kafli, kominek lepiony, tawy proste koto pieca, taw także przy 2 ścianach 2 prostych, okien szklanych $w$ drewno oprawionych 3 (...) stołów 2 stolarskiej roboty, starych, trzeci pomniejszy. Z tej izby komora (...) Z komory tej wyjście na ogród (...) W sieni naprzeciwko izbie komora (...) Tamże w sieni na górę nad izbę wschód na zawiasach żelaznych, z haczykiem i wrzeciadzem drzwi majacy.

Wreszcie lustratorzy z równie dużą precyzją analizują kolejny element kompleksu:

Budowanie na kopcu, do którego idac mostek z poręczem po obu stronach. Wchodzac do sionki drzwi na zawiasach żelaznych, $z$ wrzeciadzem $i$ hantaba. Izdebka, do niej drzwi na zawiasach, $z$ wrzeciadzem. Tamże piec biały, (z) prostych kaflów, komin, okien 2 proste, $w$ drewnie oprawione, tawy wkoło. Naprzeciwko tej izdebce komora, w niej okno szklane niedobre, proste, drzwi na zawiasach żelaznych. W tymże budowaniu naprzeciwko drzwiom siennym izdebka, gdzie łazienka była przedtym, nowo teraz zbudowana. Do niej drzwi na zawiasach 2 z zamkiem, haczykiem i skoblem, okien 2 prostych $w$ drewno, piec biaty, prosty, stót roboty stolarskiej, law przy ścienie 2, ława przy piecu stolarskiej roboty. Na tym budowaniu dach zły, barzo pogniety, już po większej części obleciat, woda koło kopca. 
Lustrację zespołu dworskiego w Szadku kończy dokładny opis budynków gospodarczych:

Przed nowym dworem piekarnia, pusta, gontami pobita, zgnieła juz. Do niej drzwi na zawiasach, z wrzeciadzem. Wchodzac do siemi po lewej ręce komórka, do niej drzwi proste $z$ wrzeciadzem, na zawiasach. Tamże w sieni ognisko, kamieniem i cegła wymurowane, podktórym piec do pieczenia chleba, komin w drzewo, nadogniskiem glina oblepiony i gontami pobity. Izba, do niej drzwi na zawiasach, $w$ niej piec prosty, zty, tamże kominek niedobry, okien 2 bez błon. Z komory izba, do niej drzwi na zawiasach, z wrzeciadzem. Przy niej chlewik nowo postawiony, słoma poszyty, do niego drzwiczki proste. Obora, do niej wrota dwoiste, przy wrotach drzwiczki. Ta obora wszystka trcina poszyta, stoma miejscami, drzewo poniekad złe, pogniełe ma; która po większej części poprawiona teraz. Kurnik stoma poszyty, drzwi do niego proste. Na podwórzu nowego dworu z przyjazdu stajnia dobra, porzadna, wszystka gontami pobita. W pót stajnie przegroda, w której sq drzwiczki. Do tej stajnie wrota na biegunach żelaznych z kunami do zawierania. Tamże sa 2 podciagi naprawione teraz niedawno. Item komórka woźnicza, drzwi do niej proste z wrzeciadzem. Nad ta stajnia góra do sypania zboża. Tam po wschodku wchodząc, drzwi na górę na zawiasach, $z$ wrzeciadzem i skoblem. Budowanie to wszystko oparkanione nowym parkanem. W tym parkanie drzwi dwoje prostych. Stodót 2 (...) Przy nich plewiarnia stoma poszyta, o 2 bojowiskach (...) Druga stodoła stara o 2 także bojowiskach, w jednym miejscu pochylona, część teraz świeżo naprawiona, stoma poszyta (...) Te stodoły nowo ostrożone kosztem JMP starosty. Także, co się wyżej specyfikowato lub poprawieto badź też zbudowato, opowiedano się od JMP starosty, że to kosztem jego działo się. Także stoły, ławy, piece, zydle to wszytko kosztem JMP starosty sprawiono ${ }^{16}$.

Biorąc pod uwagę rejestr ,prowentów” z miasta, stwierdzono ubytek liczby domów od okresu poprzedniej lustracji, z 266 do 226. Analogicznie liczba domów znajdujących się w rękach szlachty spadła z 34 do zaledwie 6 . Według relacji lustratorów stan ten wywołany był faktem celowej rozbiórki budynków prowadzonej przez przedstawicieli stanu szlacheckiego i niektórych mieszczan, na których ciążyły długi. Wyraźny wzrost niezagospodarowanych placów stanowił bardzo niekorzystną sytuację z punktu widzenia funkcjonowania miasta i wywołał kontrreakcję władz, wyrażoną słowami: Nakazujemy, aby się tego nikt nie ważyt

16 LWWK 1628-1632, cz. 2, s. 46-48. 
pod kara 14 grz. do skrzynki miejskiej należącej (...) A jeżeliby kto chciał gwattem rozbierać, tedy maja to opowiedzieć JMP staroście, aby takiego gwattu spólnie z miastem zabronie ${ }^{17}$. Dochód z tytułu czynszu na św. Marcina i św. Jana wyniósł sumarycznie odpowiednio 10 florenów i 1 grosz oraz 9 florenów i 18 groszy. Liczba komorników w mieście, analogicznie do spadku liczby budynków mieszkalnych, uległa obniżeniu, do poziomu 72 osób. Na Podgórzu Szadkowskim zamieszkiwało 16 osadników. Skarżyli się oni na bezprawny wzrost obciążeń, co dało podstawę do wydania w 1624 r. przez króla specjalnego dokumentu potwierdzającego zakres powinności feudalnych ${ }^{18}$.

W przestrzeni miasta rozwijało się w dalszym ciągu rzemiosło. Zaobserwować można spadek przedstawicieli niektórych zawodów, przy jednoczesnym wzroście zróżnicowania reprezentowanych profesji. Według lustracji odnotowano 10 krawców, 8 kuśnierzy, 40 sukienników, 3 ślusarzy, 4 kowali, 2 kołodziejów, 4 bednarzy, 3 czapników i 3 garncarzy. Wszyscy zobowiązani byli do podatku w wysokości 1 grosza $\mathrm{z}$ tytułu prowadzonej działalności. W dalszym ciągu widoczny był zastój w zakresie handlu w mieście ze względu na brak odbudowy spalonych wcześniej jatek. W Szadku funkcjonowała karczma, której jako posesor tabernae patronował wójt, zaś arendarzami zgodnie z prawem byli Żydzi. Z tym związana była produkcja słodów piwnych (ok. 900 miar, z czego 1/3 należała się mansjonarzom) i gorzałczanych (ok. 60 miar). Biorąc pod uwagę, że ogólny dochód miasta wynosił w tym czasie 1674 florenów, 10 groszy i 15 denarów, to produkcja alkoholu dostarczała z tego łącznie aż 738 florenów i 20 groszy (czyli prawie połowę dochodu $)^{19}$.

W związku z opustoszeniem miejscowego młyna końskiego, mieszczanie zobligowani byli do korzystania z młynów królewskich, których było w tym czasie trzy. Odnotowano ponadto istnienie trzech stawów: Pod Kobyłą, Leśnego i Paluchowskiego. W mieście funkcjonował także folusz, który przeszedł rozbudowę i modernizację, dzięki czemu powinni będa sukiennicy do niego jeździć i tam sukna swoje folować (...), miarę mbyńska dworowi oddawszy ${ }^{20}$.

\section{LUSTRACJA SZADKU Z 1661 R.}

Kolejna lustracja dóbr królewskich przypadła na bardzo trudny okres polityczno-gospodarczy dziejów Rzeczpospolitej, tuż po wojnie polsko-szwedzkiej, znanej w historiografii jako potop szwedzki. Zniszczenia wywołane walkami i przemarszami wojsk były ogromne. Notuje się w tym czasie spustoszenia zabudowy oraz

\footnotetext{
17 Tamże, s. 58.

18 AGAD, Metryka Koronna, ks. 169, k. 508v-509.

19 LWWK 1628-1632, cz. 2, s. 51-63.

20 Tamże, s. 61.
} 
zanik wielu form aktywności mieszkańców, co w konsekwencji przyczyniło się do regresu, a niekiedy upadku wielu miast i miasteczek. Znamienna jest na przykład relacja angielskiego kupca J. Marshalla, który podróżując wiosną $1670 \mathrm{r}$. pisał: Z Rawy do Sieradza obszar ten jak można dostrzec, byt kiedyś uprawny, teraz napotkaliśmy tu tylko trzy niezamieszkałe wsie. Pozostałe byty doszczętnie spalone, a mieszkańcy uciekli ${ }^{21}$.

Posesorem dzierżawy szadkowskiej w okresie przeprowadzonej lustracji był Hieronim Wierzbowski, chorąży łęczycki, kasztelan sieradzki, następnie wojewoda brzeski, a później wojewoda sieradzki ${ }^{22}$. Analiza wyników lustracji ukazuje stan kryzysowy zagospodarowania miasta. Ze względu na zniszczenia wojenne i związane z nimi pożary prawie $2 / 3$ istniejącej wcześniej zabudowy uległo zanikowi. $\mathrm{W}$ pierzejach rynku, poszczególnych ulicach oraz na przedmieściach zachowało się jedynie 80 budynków mieszkalnych. Domów pozostających w rękach szlachty pozostało natomiast tylko 4 . W związku z tym udział dochodów z tytułu czynszów (świętojańskiego i świętomarcińskiego) gwałtownie zmniejszył się i wynosił łącznie tylko 13 florenów i 24 grosze. Lustratorzy nie podali liczebności komorników. Ich warunki bytowe uległy radykalnemu pogorszeniu, albowiem zaprzestano pobierania od nich czynszów. Jak wynika $\mathrm{z}$ tekstu lustracji bo i sami mieszczanie w budach i chatkach małych musza się utułać i bezprzestrzeństwa swego ściskać, nie wywodzi się w prowent czynszu, którego podtug dawnych zwyczajów powinni po groszu jednym płacic $^{23}$. Z powodu depopulacji i spustoszenia zabudowy wiele zakładów rzemieślniczych zaprzestało działalności. Warto podkreślić, że w lustracji mowa jest wyłącznie o szewcach, którzy płacili czynsz roczny. Nie wymienia się natomiast przedstawicieli innych profesji, a szczególnie sukienników, którzy stanowili najliczniejszą grupę cechową w mieście jeszcze na początku XVII w. Również handel w Szadku przeżywał wyraźny kryzys. W dalszym ciągu w mieście nie było jatek, które uległy spaleniu, a ze względu na brak lokalnych zasobów ludzkich, rzeźnicy przyjeżdżający na targi z zewnątrz zwolnieni byli z powinności czynszowych. Miasto natomiast nadal czerpało zyski z tytułu prawa składu, choć furmanów przejeżdżająych podczas teraźniejszego zniszczenia i rostyrków wojennych dla ustawienia handlów, ledwo tego prowenta uczynić moga ${ }^{24}$. Niekorzystna sytuacja zapanowała także na terenie Przedmieścia Szadkowskiego, zwanego również Podgórzem. Nie dysponujemy danymi o jego zaludnieniu, ale dowiadujemy się, że doszło tam do całkowitego zaniku uprawy gruntów i z tego powodu nie przynosiły żadnych dochodów, o czym świadczyć mogą słowa: te wszystkie grunta funditus spustoszaty, ledwo miejsce znać kędy postawione byty i grunta

21 W. Zawadzki, Polska stanisławowska w oczach cudzoziemców, t. 1, Warszawa 1963, s. 324.

${ }_{22}$ Herbarz polski Kaspra Niesieckiego, t. 7, Lipsk 1841, s. 312; AGAD, Metryka Koronna, ks. 197, k. 28-29.

23 AGAD, Archiwum Skarbu Koronnego, dz. XLVI, nr 106, k. 367.

${ }^{24}$ LWWK 1659-1665, cz. 2, s. 177. 
odtogiem leża. Zaczym ad praesens JMP staroście prowent żaden od wielu lat nie idzie i cale ustat ${ }^{25}$. W dalszym ciągu zniszczony pozostał młyn koński, a zgodnie z instrukcją mieszkańcy powinni korzystać w młynów królewskich, zlokalizowanych na rzece Pichnie. $Z$ trzech istniejących wcześniej młynów zachowało się jednak tylko dwa: pierwszy nazywany Kobylski oraz drugi określany mianem Czerniak. Trzeci młyn, Leśny, uległ zanikowi. Praktycznie zaprzestano ponadto gospodarki stawowo-rybnej. Zgodnie z tekstem lustracji gospodarowanie stawem po Kobylą, na rzece Przatówce, jest mało efektywne, a pozostałe dwa, wymienione w poprzedniej lustracji, tj. Leśny i Paluchowski, są niewykorzystane.

\section{LUSTRACJA SZADKU Z 1789 R.}

Ostatnia lustracja królewszczyzn w okresie przedrozbiorowym obejmująca obszar Szadku miała miejsce u schyłku epoki stanisławowskiej, w 1789 r., w czasie odbywania się Sejmu Wielkiego ${ }^{26}$. Ówczesnym starostą szadkowskim był Daniel Suchecki, którego pełnomocnikiem w okresie lustracji pozostawał Andrzej Gorczyński, burgrabia grodzki sieradzki. Zgodnie z treścią Rewizji Praw Posesora wymienia się ponadto postać Estery Waniewskiej, określanej jako starostwa tegoż arendowana posesorka ${ }^{27}$.

Częściowy obraz zabudowy daje nam lektura Stanu Czyli Inwentarza Starostwa Szadkowskiego i Wójtostw w Tymże Starostwie. W mieście zlokalizowany był dwór w złym stanie technicznym, kryty gontem. Obejmował on z jednej strony trzy pokoje i komorę, a z drugiej strony jedną izbę z przylegającą komorą. Pod sienią znajdowała się mała piwnica. Za dworem znajdowały się zaś dwie dodatkowe komory. W skład zespołu dworskiego wchodził także browar, w złym stanie, wymagający pilnych prac naprawczych. Składał się on z dużego pomieszczenia produkcyjnego oraz małej izby z lewej strony obiektu. W izbie służącej do wytwarzania słodu znajdował się komin i piec murowany. Staraniami posesora Sucheckiego postawiony został zniszczony niegdyś koński młyn wraz sieczkarnią. Młyn był budynkiem podmurowanym, krytym gontem, choć wewnątrz niedokończonym. W obrębie kompleksu usytuowana była również mała, jednoizbowa gorzelnia, stajnia ze zniszczoną wozownią oraz trzy stodoły, z których dwie dość mocno zniszczone, zostały częściowo wyremontowane przez dzierżawcę. Uzyskujemy ponadto dane na temat obiektów inwentarskich. Wśród nich wymienić należy owczarnię, dwie stojące naprzeciw siebie obory, poddane w okresie poprzedzającym lustrację pracom renowacyjnym, a ponadto cztery drewniane chlewy do reparacyji niezdatne, bo w błotnistym miejscu stoja. W lustracji mowa

\footnotetext{
25 Tamże, s. 177.

26 Volumina Legum, t. IX, Kraków 1889, s. 77.

${ }^{27} L W W K 1789$, cz. 2, t. 1, s. 191-192.
} 
jest również o domu (być może dla pracowników dworskich) o dwóch izbach i dwóch komorach. Niedaleko tego obiektu zlokalizowana była stara kuźnia. Naprzeciw usytuowany był zajazd (austeria) z dwiema izbami oraz stajnią. Choć przeszła niewielki remont, jak stwierdzili lustratorzy, wymagała dalszych prac renowacyjnych.

Bliżej centrum miasta odnotowano budynek murowany, kryty gontem, nazywany Piekłem, który pełnił funkcję lokalnego sklepu. Przy ulicy Rzepiszewskiej znajdowała się nowa karczma. Był to obiekt z dwiema izbami, pomieszczeniem do szynku i stajnią wjezdną. Według Prowentu Intraty Rocznej wyszynk piwa w gospodzie u Gołembiewskiego obejmował 90 beczek 60 garnców (w roku następnym 102 beczki, 33 garnce), w austerii Piekło 31 beczek i 64 garnce (w drugim roku 49 beczki i 20 garnców), zaś w karczmie Na Piasku 15 beczek i 31 garnców (w kolejnym roku obejmującym lustrację 30 beczek i 66 garnców). Wyszynk gorzałki w tych gospodach wynosił w okresie dwuletnim 1049 garnców (odpowiednio 395 i $654 \mathrm{w}$ dwóch kolejnych latach: 1787 i 1788) ${ }^{28}$. Niedaleko probostwa stał młyn Grobela z dwoma kołami młyńskimi, w dobrym stanie technicznym. Drugi młyn, Wardęga, położony w kierunku Szadkowic, ze względu na zniszczenia, użytkowany był tylko okresowo ${ }^{29}$. Niestety w lustracji brakuje jakichkolwiek informacji na temat prywatnej zabudowy mieszczańskiej w Szadku. Ze względu na chęć ukazania tendencji w tym zakresie w stosunku do poprzednio przeprowadzonych lustracji, warto przytoczyć dane porównawcze zaczerpnięte z innego źródła, jakim jest taryfa podymnego z 1775 r., zgodnie z którą w Szadku znajdowało się wówczas 101 domów ${ }^{30}$. Można z całą pewnością stwierdzić w świetle lustracji, że w Szadku znajdowały się zakłady szewskie i sukiennicze, o czym świadczą czynsze z tytułu posiadania wyspecjalizowanych jatek oraz deputat 10 łokci przędzy, jaką gromada powinna oddawać dworowi. Na gruntach starościńskich prowadzona była działalność rolna. $\mathrm{O}$ ile w poprzednich lustracjach odnajdujemy jedynie informacje na temat wielkości renty feudalnej $\mathrm{w}$ formie naturaliów, o tyle w ostatniej lustracji pojawiły się dane statystyczne, ukazujące ilość zbiorów poszczególnych ziemiopłodów, co daje pośrednio obraz struktury upraw. I tak pszenicy ozimej zbiór wynosił 5 kop, pszenicy jarej odpowiednio 7 kop i 45 snopów (dane tylko jednorocznie), żyta w pierwszym roku 91 kop i 30 snopów, w drugim zaś 104 kopy, jęczmienia natomiast w pierwszym roku lustracyjnym 105 kop i 30 snopów, w kolejnym zaś 140 kop ${ }^{31}$.

28 Beczka $=72$ garnce $=288$ kwarty $=1152$ kwaterki $=271,36$ litra - w systemie miar objętości płynów wprowadzonym w 1764 r.

29 AGAD, Archiwum Skarbu Koronnego, dz. XLVI, nr 111, k. 19-20; LWWK 1789, s. 199-200.

30 Polen, oder Verzeichniß aller adlichen, geistlichen und königlichen Oerter in Polen, nach den Woiwodschaften und Districten, und mit Bemerkung der Anzahl der Rauchfänge in jedem Orte, „Magazin für die neue Historie und Geographie” 1788, t. 22, wyd. A.F. Büsching, s. 102.

31 AGAD, Archiwum Skarbu Koronnego, dz. XLVI, nr 111, k. 3-5; LWWK 1789, s. 193-194. 


\section{PODSUMOWANIE}

Analiza archiwalnych lustracji królewszczyzn okazała się doskonałym źródłem informacji na temat zagospodarowania przestrzennego Szadku w okresie nowożytnym. Przez pryzmat danych podatkowych prześledzić można zmiany liczebności i stanu technicznego zabudowy mieszkalnej, zarówno dworskiej jak mieszczańskiej, a ponadto budynków pełniących funkcje gospodarcze oraz obiektów użyteczności publicznej, takich jak gospody. Uzyskujemy ponadto wiele interesujących wzmianek dotyczących obiektów produkcyjnych, w tym zakładów rzemieślniczych, młynów i foluszy. Dowiadujemy się także pośrednio o wybranych aspektach użytkowania gruntów oraz gospodarce stawowo-rybnej.

Wykorzystane materiały źródłowe pozwalają dokonać charakterystyki zmian zagospodarowania w badanym okresie. W II połowie XVI w. w mieście dobrze rozwijał się handel i rzemiosło, funkcjonowały kramy kupieckie, zakłady cechowe, karczma prowadząca sprzedaż produkowanego lokalnie alkoholu oraz trzy młyny. Na początku XVII w. znacząco rozbudował się kompleks dworski, a w mieście znajdowało się łącznie ok. 300 budynków mieszkalnych, których liczba jednak stopniowo malała i następował wzrost niezagospodarowanych placów. W Szadku istniały liczne zakłady krawców, kuśnierzy, ślusarzy, kowali, kołodziejów, bednarzy, czapników i garncarzy. Na uwagę zasługuje bardzo liczna grupa sukienników, których działalność produkcyjną wspierał tutejszy folusz. Spadła natomiast rola handlu ze względu na pożar jatek kupieckich, zniszczony został również jeden z młynów. W II połowie XVII w. po potopie szwedzkim nastąpił wyraźny regres. W wyniku pożarów radykalnie, bo o $2 / 3$ spadła liczba domów mieszkalnych w mieście i na przedmieściu. Spustoszeniu uległo większość zakładów rzemieślniczych. W niewielkim stopniu rozwijał się handel. Zniszczony został kolejny młyn, a większość stawów była niewykorzystana. Grunty na Podgórzu leżały natomiast odłogiem. Pewne ożywienie obserwuje się dopiero w świetle lustracji z końca XVIII w. Odremontowanych zostało wówczas wiele budynków dworskich. Nastąpiła częściowa odbudowa substancji mieszkaniowej, w mieście działały prężnie aż trzy obiekty karczmarskie, wznowiły działalność zakłady rzemieślnicze oraz ponownie zaczęto uprawiać grunty na przedmieściu. 


\section{Bibliografia}

\section{Źródła}

Archiwum Główne Akt Dawnych w Warszawie:

- Archiwum Skarbu Koronnego, dz. XLVI, nr 104, k. 128-129v; nr 106, k. 367; nr 111, k. 3-5 i 19-20.

- Metryka Koronna, ks. 85, k. 460; ks. 168, k. 96-97v; ks. 169, k. 508v-509; ks. 197, k. 28-29.

- Metryka Koronna, Lustracje, dz. XVIII, sygn. 8, k. 51; sygn. 5, k. 150-151.

Herbarz polski Kaspra Niesieckiego, t. 7 i 8, Lipsk 1841.

Lustracja województw wielkopolskich i kujawskich 1564-1565, cz. 1, wyd. A. Tomczak, C. Ohryzko-Włodarska, J. Włodarczyk, Bydgoszcz 1961.

Lustracja województw wielkopolskich i kujawskich 1564-1565, cz. 2, wyd. A. Tomczak, Bydgoszcz 1963.

Lustracja województw wielkopolskich i kujawskich. 1616-1620, cz. I, wyd. Z. Górski, R. Kabaciński, J. Pakulski, Wrocław-Warszawa-Kraków 1994.

Lustracja województw wielkopolskich i kujawskich 1628-1632, cz. 2: Województwo sieradzkie, wyd. Z. Guldon, Wrocław-Warszawa-Kraków 1969.

Lustracja województw wielkopolskich i kujawskich 1659-1665, cz. 2: Województwa sieradzkie, tęczyckie, brzesko-kujawskie, inowrocławskie i ziemia dobrzyńska, wyd. Z. Górski, J. Pakulski, A. Tomczak, Torun 1996.

Lustracja województw wielkopolskich i kujawskich 1789, cz. 2: Województwo sieradzkie, t. 1: Powiaty sieradzki i szadkowski, wyd. R. Kabaciński, K. Mikulski, J. Pakulski, Toruń 2004.

Łaski J., Liber beneficiorum archidiecezji gnieźnieńskiej, wyd. J. Łukowski, t. I, Gniezno 1880.

Polen, oder Verzeichniß aller adlichen, geistlichen und königlichen Oerter in Polen, nach den Woiwodschaften und Districten, und mit Bemerkung der Anzahl der Rauchfänge in jedem Orte, „Magazin für die neue Historie und Geographie” 1788, t. 22, wyd. A.F. Büsching, s. 102.

Volumina Legum, t. IX, Kraków 1889.

\section{Literatura}

Chłapowski K., Dygdała J., Prace edytorskie nad lustracjami dóbr królewskich XVI-XVIII w., po pótwieczu, „Studia Źródłoznawcze” 2005, t. 43, s. 161-171.

Górska K., Przyczynek do krytyki rejestrów poborowych XVI wielu, „Studia Źródłoznawcze" 1957 , t. 1, s. 184-189.

Guldon Z., Uwagi w sprawie przydatności badawczej rejestrów poborowych z XVI wieku, „Zapiski Historyczne” 1966, t. 31, nr 1, s. 73-80.

Janczak J., Ludność powiatu szadkowskiego w okresie Sejmu Czteroletniego, „Przeszłość Demograficzna Polski” 1975, t. 8, s. 3-55. 
Kajzer L., Dwór królewski - zapomniany zabytek Szadku, „Biuletyn Szadkowski” 2002, t. 2, s. 7-21.

Kulesza M., Rozwój przestrzenny i współczesna struktura morfogenetyczna Szadku, „Biuletyn Szadkowski” 2003, t. 3, s. 55-71.

Marszał T., Szadek. Monografia miasta, Szadek 1995.

Parczewski A.J., Monografia Szadku, Warszawa 1870.

Puś W., Dzieje Szadku do początku XVI w., „Na Sieradzkich Szlakach” 1995, R. 11, nr 3.

Senkowski J., Lustracje, rewizje oraz inwentarze dóbr królewskich, [w:] J. Karwasińska (red.), Archiwum Główne Akt Dawnych w Warszawie. Przewodnik po zespołach, Warszawa 1973, s. 97-108.

Słownik geograficzny Królestwa Polskiego i innych krajów słowiańskich, t. XI, B. Chlebowski, W. Walewski (red.), Warszawa 1890.

Stoynowski A., Użytkownicy królewszczyzn województw sieradzkiego i łęczyckiego oraz ziemi wieluńskie (XVI-XVIII w.), „Rocznik Łódzki” 1975, t. 23, s. 315-329.

Wisińska-Kluba M., Szadek w XVI-XVIII w., „Na Sieradzkich Szlakach” 1995, R. 11, nr 3. Zawadzki W., Polska stanisławowska w oczach cudzoziemców, t. 1, Warszawa 1963.

Żytkowicz L., Lustracje dóbr królewskich XVI-XVIII wieku. Geneza i realizacja wydawnictwa, „Studia Źródłoznawcze” 1973, t. XVIII, s. 191-197.

[Artykuł wpłynął: kwiecień 2020; akceptacja: czerwiec 2020]

\section{SPATIAL DEVELOPMENT OF SZADEK IN MODERN PERIOD IN THE LIGHT OF ROYAL ESTATE INSPECTIONS}

\section{Summary}

The article presents the results of geographical and historical research on spatial development of Szadek from XVI to XVIII century. The analysis was conducted on the basis of source materials in the form royal land inspections carried out in 1564, 1616, 1628, 1661 and 1789. XVI and early XVII centuries are a period of dynamic economic growth. Szadek comprised about 300 residential buildings and a manorial complex. Trade and crafts flourished in the town in numerous market stalls and manufacturing facilities. In mid-XVII century, as a result of wartime destruction, a period of recession began. The number of houses decreased considerably, many manufacturing sites disappeared, trade collapsed, and agricultural activity in suburban areas was no longer continued. At the end of XVIII century there were some symptoms of economic revival. The number of residential buildings increased and their technical condition improved, services and production (including crafts and agriculture) were reactivated.

Keywords: Szadek, town, spatial development, inspection, royal estate, modern period 